\title{
Evidence of alpha 7 nicotinic acetylcholine receptor expression in retinal pigment epithelial cells
}

\author{
VICTORIA MANEU, ${ }^{1,2}$ GUILLERMO GERONA, ${ }^{1}$ LAURA FERNÁNDEZ,${ }^{3}$ NICOLÁS CUENCA, ${ }^{3}$ AND \\ PEDRO LAX ${ }^{3}$ \\ ${ }^{1}$ Departamento de Óptica, Farmacología y Anatomía, Universidad de Alicante, Alicante, Spain \\ ${ }^{2}$ Instituto Teófilo Hernando de I+D del Medicamento, Universidad Autónoma de Madrid, Madrid, Spain \\ ${ }^{3}$ Departamento de Fisiología, Genética y Microbiología, Universidad de Alicante, Alicante, Spain \\ (Received June 28, 2010; Accepted August 6, 2010; First Published Online October 8, 2010)
}

\begin{abstract}
Some evidence suggests that retinal pigment epithelium (RPE) can express nicotinic acetylcholine receptors (nAChRs) as described for other epithelial cells, where nAChRs have been involved in processes such as cell development, cell death, cell migration, and angiogenesis. This study is designed to determine the expression and activity of $\alpha 7 \mathrm{nAChRs}$ in RPE cells. Reverse transcriptase (RT)-PCR was performed to test the expression of nicotinic $\alpha 7$ subunit in bovine RPE cells. Protein expression was determined by Western blot and by immunocytochemistry. Expression of nicotinic $\alpha 7$ subunits was also analyzed in cryostat sections of albino rat retina. Changes in protein expression were tested under hypoxic conditions. Functional nAChRs were studied by examining the $\mathrm{Ca}^{2+}$ transients elicited by nicotine and acetylcholine stimulation in fura-2-loaded cells. Expression of endogenous modulators of nAChRs was analyzed by RT-PCR and Western blot in retina and RPE. Cultured bovine RPE cells expressed nicotinic receptors containing $\alpha 7$ subunit. RT-PCR amplified the expected specific $\alpha 7$ fragment. Western blotting showed expression at the protein level, with a specific band being found at $57 \mathrm{kDa}$ in both cultured and freshly isolated RPE cells. Expression of nAChRs was confirmed for cultured cells by immunofluorescence. Immunohistochemistry confirmed $\alpha 7$ receptor expression in rat RPE retina. $\alpha 7$ receptor expression was down-regulated by long-term hypoxia. A small subpopulation of RPE cultured cells showed functional nAChRs, as evidenced by the selective response elicited by nicotine and acetylcholine stimulation. Expression of the endogenous nicotinic receptors' modulator lynx 1 was confirmed in bovine retina and RPE, and expression of lynx 1 and other endogenous nicotinic receptor modulators (SLURP1 and RGD1308195) were also confirmed in rat retina. These results suggest that nAChRs could have a significant role in RPE, which may not be related to the traditional role in nerve transmission but could more likely be related to the nonneuronal cholinergic system in the eye.
\end{abstract}

Keywords: RPE, Nicotinic receptors, Gene expression, lynx1

\section{Introduction}

Nicotinic acetylcholine receptors (nAChRs) are neurotransmittergated ion channels that are widely distributed throughout the nervous system, where they have been attributed an important role in processes such as learning and memory. Their deficit has been related to diseases, such as Alzheimer's and Parkinson's as well as to schizophrenia (Lindstrom, 1997; Newhouse et al., 1997). nAChRs are formed by the homomeric or heteromeric combination of five protein subunits. At least 12 different subunits have been described in the mammalian nervous system $(\alpha 2-\alpha 10$ and $\beta 2-\beta 4)$, which can coassemble to form functional pentamers with different properties depending on their composition (Millar, 2003; Gotti \& Clementi, 2004).

It is now fully recognized that $\mathrm{nAChRs}$ also play important roles in nonexcitable cells. Nonneuronal cholinergic systems are

Address correspondence and reprint requests to: Pedro Lax, Departamento de Fisiología, Genética y Microbiología, Universidad de Alicante, Carretera San Vicente del Raspeig s/n. 03690 San Vicente del Raspeig, Alicante, Spain. E-mail: pedro.lax@ua.es expressed in different cells and tissues and are involved in the regulation of their functions. Moreover, it has been shown that cholinergic dysfunction is related to the pathophysiology of diseases even though a systematic analysis of all the components of the nonneuronal cholinergic system in different diseases has not yet been performed (Kawashima \& Fujii, 2008; Wessler \& Kirkpatrick, 2008). Thus, expression of nAChRs has been reported in several types of cells, including the epithelial cells of bronchial epithelium (Maus et al., 1998; Wang et al., 2001), keratinocytes (Zia et al., 2000), nasal epithelium (Blank et al., 1997), vascular endothelial cells (Macklin et al., 1998; Wang et al., 2001), or lymphocytes and peripheral blood cells (Toyabe et al., 1997; Sato et al., 1999; Benhammou et al., 2000). The nAChRs have also been involved in different cell processes (reviewed by Wessler \& Kirkpatrick, 2008). In keratinocytes, $\alpha 7$ nicotinic receptors have been proposed as mediators in maturation, differentiation, migration, and apoptosis (Zia et al., 2000; Nguyen et al., 2001; Chernyavsky et al., 2004). It has also been stated that $\alpha 3$ and $\alpha 7$ receptors control the migratory function of these cells through different effector proteins (kinases and GTPases). 
Nicotinic receptors are modulated by different conditions and agents. In this sense, hypoxia appears to modulate $\alpha 7 \mathrm{nAChRs}$ in cholinergic and noncholinergic systems, both increasing and decreasing expression of nicotinic receptors, depending on the conditions tested. For instance, Heeschen et al. (2002) showed that a hypoxic stimulus of $4 \mathrm{~h}$ increases expression of $\alpha 7 \mathrm{nAChRs}$ in human umbilical vein endothelial cells. Otherwise, it has been reported that long-term hypoxia decreases the expression of nicotinic $\alpha 7$ receptors in the adrenomedullar gland (Ducsay et al., 2007).

In vivo nonneuronal activity of $\mathrm{nAChRs}$ is also modulated by some members of the Ly-6/neurotoxin gene family, such as SLURP1, SLURP-2, or lynx1, among others (Miwa et al., 1999; Grando, 2008; Kawashima \& Fujii, 2008). Lynx 1, homologous to $\alpha$-bungarotoxin, colocalizes with $\alpha 7$ and $\beta 2$ nicotinic subunits and acts as an allosteric modulator of nAChRs in vivo, balancing neuronal activity. It has been proposed that lynx 1 maintains both a low ACh sensitivity and a safety margin against agonist overstimulation of nAChRs (Miwa et al., 2006). Expression of these endogenous modulators of nAChRs such as lynx1, SLURP-1, or SLURP-2 has not yet been described in the retina, although some works have reported the expression of SLURP1 in whole eye preparation (Mastrangeli et al., 2003) or tears (Favre et al., 2007).

There is some evidence suggesting that the retinal pigment epithelium (RPE) can express nAChRs. RPE is an epithelial monolayer of highly specialized nonexcitable cells, which is located between the neural retina and the vascular choroid. This layer plays a key role in the mechanical and metabolic support of photoreceptors. Moreover, evidence suggests that RPE is also involved in functions, such as eye growth control (Stone et al., 2001). This process may involve cholinergic mechanisms that act through muscarinic receptors. In this sense, a number of studies have shown that the muscarinic antagonist atropine delays the development of myopia in several animal models (Raviola \& Wiesel, 1985; Stone et al., 1991; Tigges et al., 1999). Stone et al. (2001) suggest a role for nAChRs on RPE function. They reported that chlorisondamine, which is a substance that accumulates in neurons with nicotinic receptors, induces RPE layer degeneration, while other classical nicotinic antagonists cause no damage to the epithelial layer. This fact led the authors to suggest the possibility that RPE could also express nAChRs.

The aim of this work was to characterize the presence and functionality of $\alpha 7$ nAChRs in RPE and test their modulation by stimulus such as hypoxia as well as to explore the expression of endogenous modulators of $\mathrm{nAChRs}$ in the retina that could influence activity of nAChRs in RPE.

\section{Materials and methods}

\section{Cell culture}

RPE from cow eyes obtained from the municipal slaughterhouse in Orihuela (Spain) was isolated using standard techniques for cellular dissociation and isolation. Briefly, after the retinas were removed, the eyecups were incubated with $0.5 \%$ trypsin-EDTA for $45 \mathrm{~min}$. Dissociated cells were concentrated by centrifugation and resuspended in dulbecco's modified eagle medium containing antibiotics $(50 \mu \mathrm{g} / \mathrm{ml}$ gentamicin and $2.5 \mu \mathrm{g} / \mathrm{ml}$ amphotericin B) and bovine fetal serum (FCS, 10\%). The cells were grown on plastic flasks at $37^{\circ} \mathrm{C}$ in $5 \% \mathrm{CO}_{2}$. The culture medium was changed every 2 days. Primary cultures aged between 4 and 6 weeks were subcultured following treatment with trypsin/EDTA. In order to avoid opacities caused by the melanin granules present on the RPE explants and first passages, unless otherwise indicated, cells cultures were used after four passages, where pigmented granules were not present. The confluent cultures appeared to be monolayered, with RPE cells showing a flattened appearance.

\section{Reverse transcriptase-PCR protocol}

Total RNA was extracted using the GenElute Mammalian Total RNA Miniprep Kit (Sigma, St. Louis, MO), according to the manufacturer's instructions. Contaminating DNA was removed using DNAse I (1 U/ $\mu$ g total RNA; Fermentas, Glen Burnie, MD). Reverse transcription was performed with $1 \mu \mathrm{g}$ RNA in the presence of $1.25 \mu \mathrm{M}$ random nonamers (Sigma), $1 \mathrm{mM}$ dNTPs (Fermentas), $20 \mathrm{U}$ of ribonuclease inhibitor (Fermentas), $50 \mathrm{mM}$ Tris- $\mathrm{HCl}(\mathrm{pH}$ 8.3), $50 \mathrm{mM} \mathrm{KCl}, 4 \mathrm{mM} \mathrm{MgCl}_{2}, 10 \mathrm{mM}$ dithiothreitol, and $200 \mathrm{U}$ of reverse transcriptase (RT, RevertAid M-MuLV Reverse Transcriptase; Fermentas) at $42^{\circ} \mathrm{C}$ for $60 \mathrm{~min}$. Negative controls without RT were added. For the PCR reaction, we used specific primers for $\alpha 7$ nicotinic receptor subunits, based on Criado et al. (1997). As control amplifications, we used the glyceraldehyde-3-phosphate dehydrogenase (GAPDH) primers described by Yuan et al. (2003). The following CRALBP- and RPE65-specific oligonucleotides were used for RPE characterization: CRALBP forward: GAAGAGGAACAGGAGCTCCG, CRALBP reverse: CTTTGAACCGAGCTGGGAAGG, RPE65 forward (described by Vogel et al., 2007): TGGAGATTAACATCCCCGTCACC, and RPE65 reverse: TATCAGCTGTAGAGGACTTTGGCT.

To analyze endogenous modulator expression, the primers used were the following: lynx1 bovine forward: CCACATCCCTGCTCTCACTC, reverse: GTGGCCAGGAGTATAAGGGC; SLURP1 rat forward: CCACGGCCATTAACTCATGC, reverse: CACGGAAGCAACAGAAGACAG; RGD1308195 rat forward (based on Moriwaki et al., 2007): ATGAGGCTTCCCTTCTGGTTC, reverse (based on Moriwaki et al., 2007): TCAGTCCCTGTTGCAGAGATT; and lynx1 rat forward: CATGACCCACTTGCTGACAG, reverse: GGATGAAGGTGAGGAAGTCC.

Complementary DNA (cDNA) was PCR amplified under standardized conditions as follows: denaturation at $94^{\circ} \mathrm{C}$ for 2 min, followed by 35 cycles of $30 \mathrm{~s}$ each at $94^{\circ} \mathrm{C}, 1 \mathrm{~min}$ at $57^{\circ} \mathrm{C}$ (CRALBP and RPE65) or $55^{\circ} \mathrm{C}(\alpha 7)$ or $30 \mathrm{~s}$ at $59.5^{\circ} \mathrm{C}$ (bovine lynx1, rat SLURP1, and RGD1308195) or $58^{\circ} \mathrm{C}$ (rat lynx1), 1 min at $72^{\circ} \mathrm{C}$, and a final elongation step at $72^{\circ} \mathrm{C}$ for $15 \mathrm{~min}$. Negative control without cDNA was present in all amplifications. PCR products were separated by electrophoresis in 1.5\% agarose gels. Identity of the amplified sequences was confirmed by RT-PCR.

\section{Western blotting}

Western blot was performed using standard techniques. After washing with sodium phosphate-buffered saline (PBS), the dissociated cells were lysed in the presence of a protease inhibitor cocktail from Sigma. Protein concentrations were determined by the Bradford method, using the Bio-Rad Protein Assay Dye Reagent (Bio-Rad, Herculez, CA). Denatured proteins were run on $10 \%$ sodium dodecyl sulfate-polyacrylamide gels. Proteins were blotted onto polyvinylidene difluoride membranes. Bands were identified using Lumi-light Western Blotting Substrate (Roche Applied Science, Indianapolis, IN) according to the manufacturer's instructions. Molecular weight standard markers were used (Pageruler Unstained Protein Ladder and Prestained Protein Molecular Weight Marker; Fermentas). For $\alpha 7$ nicotinic subunit, primary antibody anti- $\alpha 7$ monoclonal antibody mAb319 (Sigma) was used at $2.5 \mu \mathrm{g} / \mathrm{ml}$. 
Secondary antibody: $40 \mathrm{ng} / \mathrm{ml}$ goat anti-rat $\mathrm{IgG}$ conjugated with horseradish peroxidase (HRP) (Jackson Immunoresearch Laboratories, West Grove, PA). For lynx-1 detection, primary antibody T-15 (Santa Cruz Inc, Santa Cruz, CA) was used at $2 \mu \mathrm{g} / \mathrm{ml}$. Secondary antibody: donkey anti-goat IgG-HRP conjugated (Santa Cruz Inc) at $0.2 \mu \mathrm{g} / \mathrm{ml}$. The anti- $\beta$-actin monoclonal antibody (clone AC-15) was used as loading control.

\section{Immunocytochemistry for cultured cells}

Using standard techniques, RPE cells were grown on glass coverslips until confluence, washed with PBS, and fixed for 20 min with $4 \%$ paraformaldehyde in PBS at $4{ }^{\circ} \mathrm{C}$. Cells were permeabilized with $0.2 \%$ Triton X-100 in PBS for 20 min. Nonspecific binding was blocked by incubating with $1 \%$ BSA in PBS for 45 min at room temperature. Cells were incubated with primary antibody in PBS plus $1 \%$ bovine serum albumin (BSA) overnight at $4{ }^{\circ} \mathrm{C}$ in a wet chamber. Secondary antibody was applied in PBS for $1 \mathrm{~h}$ at room temperature. Cells were observed with Leica confocal microscopy (Leica TCS SP2; Leica Microsystems, Wetzlar, Germany). Negative controls lacking primary and secondary antibodies were added. The thin morphology of the cultured monolayers limited the use of confocal Z-sections and discriminations about cell polarization and labeling distribution.

\section{Immunohistochemistry for tissue sections}

Three Sprague Dawley were anesthetized with a lethal dose of ketamine $(0.5 \mathrm{~g} / \mathrm{kg}$ i.p.) and eyes were enucleated. The eyecups were fixed in $4 \%$ paraformaldehyde in $0.1 \mathrm{M} \mathrm{PBS}$ at $\mathrm{pH} 7.4$ for $2 \mathrm{~h}$ and then washed in $0.1 \mathrm{M}$ PBS before being cryoprotected in $10 \%$ sucrose for $0.5 \mathrm{~h}, 20 \%$ sucrose for $1 \mathrm{~h}$, and $30 \%$ sucrose overnight at $4^{\circ} \mathrm{C}$. The next day, they were embedded in optimal cutting temperature compound and cut into $14-\mu \mathrm{m}$ thick radial sections on a cryostat and mounted on glass slides. Sections were incubated in $10 \%$ normal donkey serum (Jackson Immunoresearch Laboratories) to avoid nonspecific staining. Without washing, they were then immunostained for rat anti- $\alpha 7$ nicotinic receptor subunit antibody diluted in PBS containing $0.5 \%$ Triton X-100. Sections were incubated overnight at room temperature. The next day, sections were washed in $0.1 \mathrm{~m} \mathrm{PBS}$. To visualize antibody binding patterns, they were transferred to donkey anti-rat IgG coupled to fluorescein isothiocyanate (FITC) in 0.1 м PBS $0.5 \%$ Triton X-100 for $1 \mathrm{~h}$. Finally, the sections were washed in 0.1 м PBS, mounted in watermount (Vector Laboratories, Burlingame, CA), and coverslipped for viewing by confocal microscopy. To control for nonspecific staining, some sections were stained omitting the primary antibody.

Primary antibodies: $5 \mu \mathrm{g} / \mathrm{ml} \mathrm{mAb319} \mathrm{(Sigma)} \mathrm{for} \alpha 7$ nicotinic subunit. For RPE characterization, $4 \mu \mathrm{g} / \mathrm{ml}$ of goat polyclonal antiCRALBP (L-19) antibody were used (Santa Cruz Inc). Secondary antibodies: Goat anti-rat Alexa $546(10 \mu \mathrm{g} / \mathrm{ml}$; Molecular Probes, Eugene, OR), donkey anti-rat Alexa $488(10 \mu \mathrm{g} / \mathrm{ml}$; Molecular Probes), and donkey anti-goat $4 \mu \mathrm{g} / \mathrm{ml}$ (Santa Cruz Inc). Negative controls without primary or/and secondary antibodies were included.

\section{Fluorescence measurements}

Fluorescence determinations were made using a conventional fluorescence microscopy system. Prior to the recordings, cells were incubated $\left(37^{\circ} \mathrm{C}\right)$ with the fluorescent $\mathrm{Ca}^{2+}$ indicator fura-2 acetoxy methyl ester (fura-2 AM, $4 \mu \mathrm{M}$; Molecular Probes) for 45 min in culture medium. After extensive washing with external solution, the cells were tested with brief applications of $200 \mu \mathrm{M}$ nicotine or $200 \mu \mathrm{M}$ acetylcholine plus $0.5 \mu \mathrm{M}$ atropine sulfate to block muscarinic responses. In order to prevent $\mathrm{nAChR}$ desensitization, successive nicotine and acethylcholine applications were separated by at least 60 -s intervals. In some experiments, the external medium was supplemented with $10 \mathrm{mM} \mathrm{Ca}^{2+}(12 \mathrm{mM}$ final concentration) in order to amplify the fluorescence response. The level of intracellular free $\mathrm{Ca}^{2+}$ concentration was taken as the ratio between the digital images obtained with 340 and 380-nm excitation wavelengths. Emission was monitored at $510 \mathrm{~nm}$. During recordings, cells were continuously superfused using a gravitydriven perfusion system with separate tubes for normal and drugcontaining external solutions. The tube ends were positioned 50-100 $\mu \mathrm{m}$ away from the cells and connected on the other side to a fast exchanger system (RSC-200; Biologic, Claix, France).

\section{Hypoxia induction}

Flasks containing approximately $7 \times 10^{6}$ bovine RPE and glass coverslips containing RPE confluent cultures were incubated without FCS in a sealed incubator at $3 \% \mathrm{O}_{2}$ for $72 \mathrm{~h}$. Control cells were maintained in normoxic conditions. After the stimulus, flask cells were collected and total proteins were immunoblotted. Cells in coverslips were fixed and used for immunofluorescence. Both were probed against mAB319 antibody for $\alpha 7 \mathrm{nAChR}$.

\section{Solutions and chemicals}

The external solution had the following composition (in millimolar): $\mathrm{NaCl}, 140 ; \mathrm{KCl}, 5.6 ; \mathrm{MgCl}_{2}, 2 ; \mathrm{CaCl}_{2}, 2$; Glucose, 10 ; and HEPES$\mathrm{NaOH}, 10 ; \mathrm{pH}$ 7.4. Culture media were purchased from GIBCO (Grand Island, NY). Unless otherwise indicated, all the other chemicals used came from Sigma.

\section{Results}

\section{RPE characterization}

Using specific oligonucleotides for the specific RPE markers CRALBP and RPE65, messenger RNA (mRNA) expression was shown by RT-PCR from RPE cultured cell RNA. Sequence was confirmed by DNA sequencing. Moreover, $100 \%$ of cultured monolayers were stained with a goat polyclonal anti-CRALBP antibody (Fig. 1A-1C).

\section{$\alpha 7$ nAChRs mRNA expression}

In order to test for the presence of nAChRs in RPE, the expression of $\alpha 7$ nicotinic receptor subunits was analyzed by RT-PCR in RPE cultured cells. As shown in Fig. 1D, the oligonucleotide primers for nicotinic $\alpha 7$ subunit (see Materials and methods) amplified a $280 \mathrm{bp}$ fragment. This same fragment was also amplified when RNA from total retina was used (positive control). Negative controls did not amplify any fragment. The GAPDH primers described by Yuan et al. (2003) (see Materials and methods) amplified a 238 bp band corresponding to an mRNA template. No 458 bp band from contaminating DNA was observed (not shown).

\section{Protein expression}

To determine whether transcripts encoding the $\alpha 7$ nicotinic subunits detected in RPE by RT-PCR were translated, Western blotting was performed with cultured RPE cells. Total retina protein extract was used as positive control. Nicotinic $\alpha 7$ subunit expression was 
A

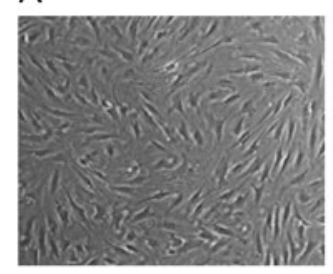

B

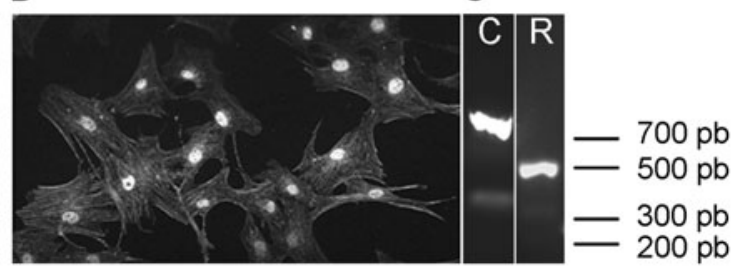

D

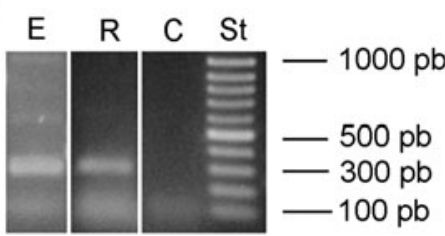

F

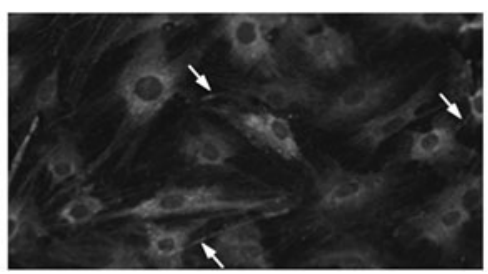

E

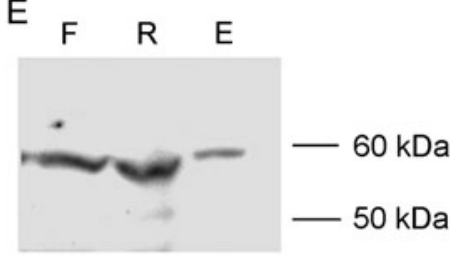

G

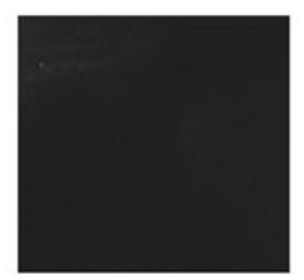

Fig. 1. Bovine RPE cells characterization and expression of $\alpha 7 \mathrm{nAChRs.} \mathrm{(A)} \mathrm{Representative} 10 \times$ image of a four-passages culture. Cells were cultured for up to 7 days till they were grown to confluence. (B) Representative RPE cell culture stained with a goat polyclonal antibody against the RPE-specific marker CRALBP. (C) RT-PCR amplification with specific primers for CRALBP (C) and RPE-65 (R). (D) RT-PCR amplification from bovine RPE mRNA. $1 \mu \mathrm{g}$ of total RNA purified from cultured RPE (E) and whole retina (R) was reverse transcribed and amplified with specific oligonucleotides for $\alpha 7$ nicotinic subunit. Negative PCR control without cDNA (C) and RNA standards (St) are also shown. A total volume of $12.5 \mu \mathrm{l}$ was loaded in each lane, onto ethidium bromide-stained $1.5 \%$ agarose gel. (E) Western blot from freshly isolated RPE (F), total retina (R), and cultured RPE (E) total proteins expected immunoreactive bands for anti- $\alpha 7$ is observed at $57 \mathrm{kDa}$. Monoclonal antibody mAb319 HRP conjugated was used. Each lane contained $20 \mu \mathrm{g}$ of total protein. (F) Immunocytochemistry confocal images of representative RPE cells in culture labeled with mAb319 antibody (against $\alpha 7 \mathrm{nAChRs).} \mathrm{Note} \mathrm{the}$ immunoreactive prolongations of cultured cells marked by arrows. (G) Representative negative control image without primary antibody.

also tested in freshly isolated RPE cells. Samples were probed with anti- $\alpha 7$ monoclonal antibody mAb319. As shown in Fig. 1E, mAb319 detected a $\sim 57 \mathrm{kDa}$ band corresponding, which was also present in all three protein extracts.

Immunofluorescence staining using antibodies against $\alpha 7$ subunit was performed in cultured RPE cells to confirm the expression of nAChRs on these cells. As can be seen in Fig. 1F, fluorescence activity was observed under the microscope in RPE cells labeled with mAb319, indicating the expression of $\alpha 7$ nicotinic subunits. Fluorescence was mostly distributed around the cell nucleus. No evident labeling was observed when no primary antibody was added (Fig. 1G), or when the secondary antibody was absent (not shown).

\section{Effect of hypoxia on expression of $\alpha 7 n A C h R s$}

In order to study the possible modulator effect of hypoxia on expression of $\alpha 7 \mathrm{nAChRs}$ in RPE cells, we applied a long-term hypoxia stimulus of $72 \mathrm{~h}$ to the RPE cell culture. After this time, protein extracts were probed with mAb319 antibody. As Fig. 2 shows, $\alpha 7$ expression decreased significantly after long-term hypoxia compared with normal conditions.

\section{Functional nAChRs detection}

In order to test for the presence of functional nAChRs in RPE in culture, we examined the $\mathrm{Ca}^{2+}$ transients elicited by both nicotine and acetylcholine $(200 \mu \mathrm{M})$ in fura-2-loaded cells. As shown in Fig. 3A and 3B, a small subset of fura-2-loaded RPE cells displayed an apparent elevation of intracellular free calcium concentration when stimulated with nicotine pulses (four responsive cells from a total of 70 optic fields viewed, representing $0.18 \%$ of total cells). Similar $\mathrm{Ca}^{2+}$ transients were observed when $200 \mu \mathrm{M}$ acetylcholine was applied (29 responsive cells in 50 microscopic fields, representing
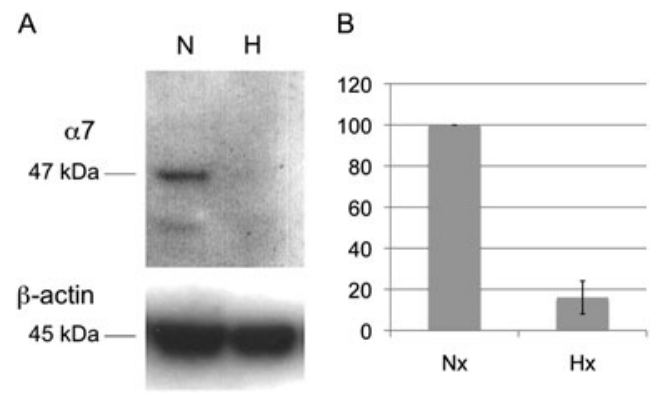

Fig. 2. Hypoxia modulation of expression of $\alpha 7$ nAChRs. (A) Western blot showing total proteins extract from RPE cells maintained in hypoxia for $72 \mathrm{~h}$ $(\mathrm{H})$ or in control normoxic conditions $(\mathrm{N})$, probed with mAb319 antibody. Bands for $\beta$-actin expression are shown as control. (B) Histogram showing expression of $\alpha 7 \mathrm{nAChRs}$ normalized to $\beta$-actin under control (normoxia) and hypoxia conditions. The values represent the means \pm S.D. from triplicates. 


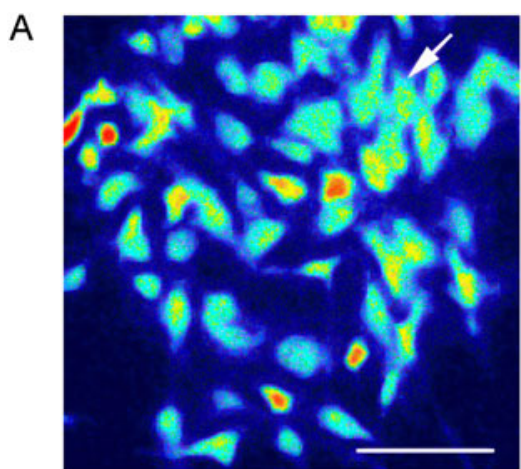

C

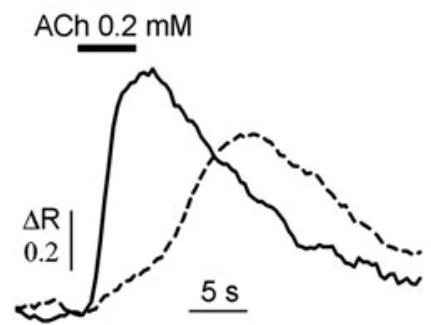

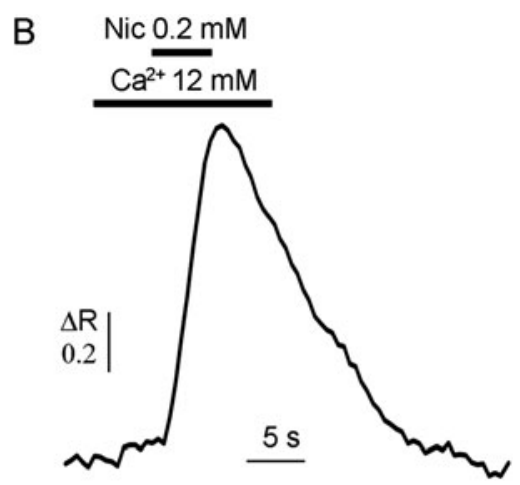

D

ACh $0.2 \mathrm{mM}$ Atropine $0.5 \mu \mathrm{M}$

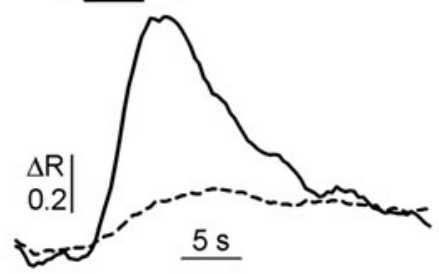

Fig. 3. Nicotine- and acetylcholine-evoked responses in cultured RPE cells. (A) Typical RPE cells in culture seen under fluorescence microscopy. Cells were incubated with the fluorescent $\mathrm{Ca}^{2+}$ indicator fura-2 acetoxy methyl ester for $45 \mathrm{~min}$. Bar $100 \mu \mathrm{m}$. (B) Intracellular $\mathrm{Ca}^{2+}$ transient elicited by nicotine (Nic) application in the cultured cell pointed at in (A) by the arrow. In order to obtain measurable responses, external medium was supplemented with $10 \mathrm{mM} \mathrm{Ca}^{2+}$ prior, during, and after the nicotine pulse. Horizontal black bars indicate the time point and duration of drug applications. (C) Intracellular $\mathrm{Ca}^{2+}$ response evoked by acetylcholine (ACh) on another two single RPE cells. (D) Intracellular $\mathrm{Ca}^{2+}$ response recorded in the same cells than in (C) when acetylcholine was coapplied with atropine sulfate.

$2 \%$ of the cells, Fig. 3C). However, only a subset of acetylcholinesensitive RPE cells (approximately 10\%) responded to $200 \mu \mathrm{M}$ acetylcholine when coapplied with $0.5 \mu \mathrm{M}$ atropine sulfate, a selective inhibitor of muscarinic acetylcholine receptors, resulting in a responsiveness of $0.21 \%$ (Fig. 3D).

\section{Tissue sections}

To further assess expression of $\alpha 7 \mathrm{nAChRs}$ in RPE, sections of albino rat retina were immunostained with antibodies against $\alpha 7$ nAChRs. Fig. 4A shows pigment epithelial cells immunoreactivity for $\alpha 7$ antibodies. An increase of immunoreactivity was found in the apical surface of these cells. No immunostaining was found in control sections (Fig. 4B, 4D, and 4F). In the retinal sections where the photoreceptors' outer segment was not detached, the immunostained apical processes of the pigment epithelium were identified, located between outer segments of the photoreceptors (Fig. 4C and $4 \mathrm{E}$, arrows).

\section{Expression of endogenous modulators of $n A C h R s$}

In order to test the expression of endogenous modulators of nAChRs in the retina and RPE, we tested the expression of lynx 1 (a member of Ly-6/neurotoxin gene family) reported as $\alpha 7$ modulator. By using total mRNA from bovine retina and RPE and with specific primers, RT-PCR amplified a band of $371 \mathrm{pb}$ corresponding to the lynx 1 gene in both bovine retina and freshly isolated RPE (Fig. 5A). By Western blot, we detected a single band of $17 \mathrm{kDa}$, which was higher than the expected 9-kDa band. The same fragment size was obtained for the rat brain sample used as positive control. Although further investigation is needed to clarify this aspect, it could be due to protein phosphorylation (Fig. 5B). The same positive results for RT-PCR amplification and Western blot analysis were obtained for rat retina (not shown). We also obtained positive RT-PCR amplification for lynx1, RGD1308195, and SLURP-1 expression in rat retina (Fig. 5C).

\section{Discussion}

The present work provides evidence that $\alpha 7 \mathrm{nAChRs}$ are present in RPE cells. Stone et al. (2001) had already reported that chlorisondamine, which is a substance that accumulates in neurons with nicotinic receptors, induced RPE layer degeneration, thus suggesting the possibility of expression of nAChRs in RPE cells. However, to our knowledge, this is the first direct evidence that nAChRs are expressed in RPE. These nicotinic receptors can be part of the nonneuronal cholinergic system in the eye.

The nAChRs are widely expressed in the eye. The retina is one of the tissues that expresses the greatest variety of nAChRs. Nicotinic receptors have a specific distribution among retinal layers, and their expression is regulated during development and by visual experience (Vailati et al., 2003; Moretti et al., 2004; Marritt et al., 2005). Acting through nAChRs, acetylcholine seems to play an important role in retinal and central visual pathways. It is possible that the increased expression of certain receptor subtypes is dependent on activity and only appears after the first use of the visual system (Stone et al., 2001; Vailati et al., 2003; Moretti et al., 2004; Marritt et al., 2005). It has also been demonstrated that visual deprivation triggers changes in expression of $\mathrm{nAChRs}$ (Moretti et al., 2004).

Understanding of the nonneuronal cholinergic system is just beginning to emerge. ACh is present in the vast majority of human 


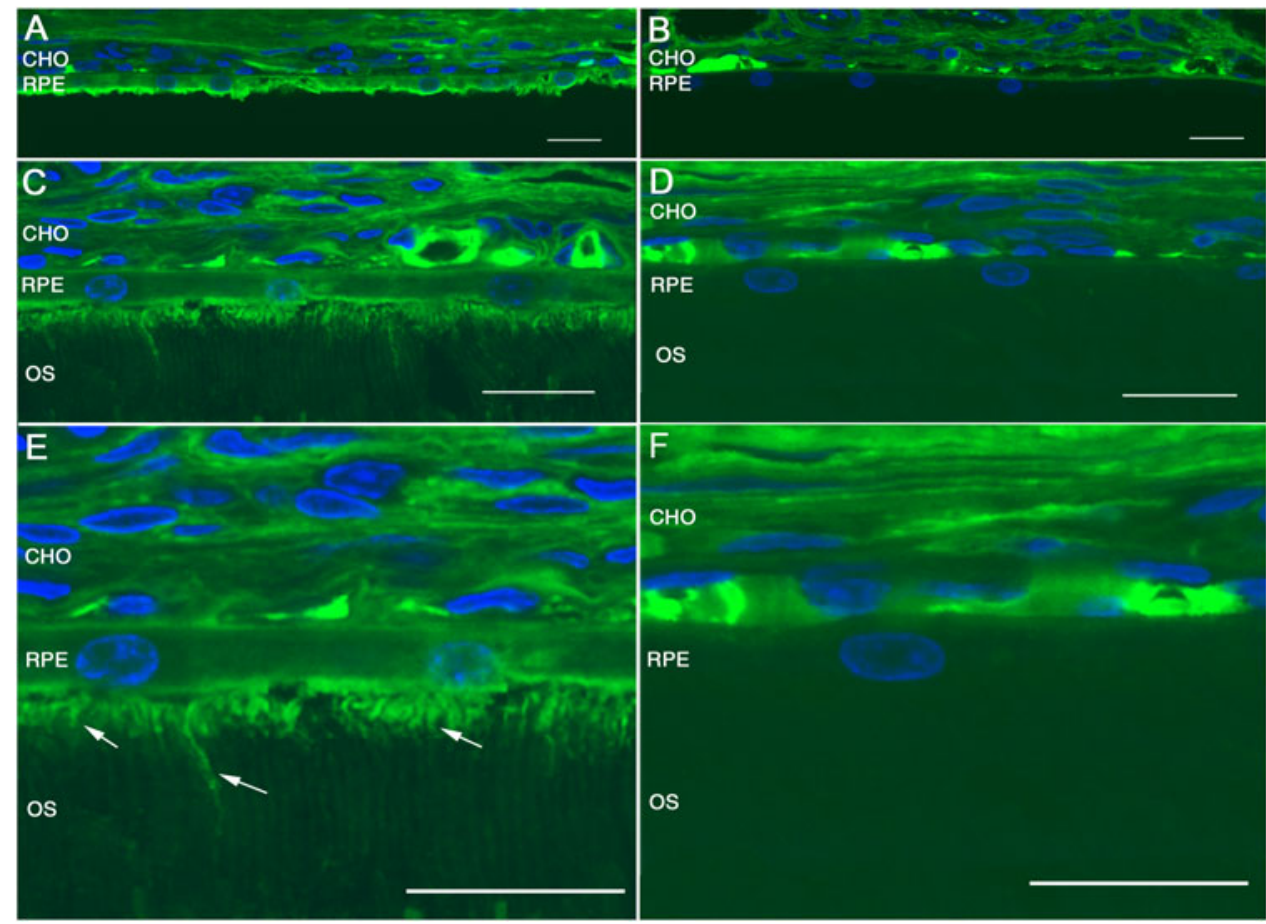

Fig. 4. Immunohistochemistry confocal images of expression of $\alpha 7 \mathrm{nAChRs}$ in rat RPE. (A, C) Vertical section of rat retina showing pigment epithelium cells labeled with antibodies against $\alpha 7 \mathrm{nAChRs.} \mathrm{(B,} \mathrm{D)} \mathrm{Control} \mathrm{retinas.} \mathrm{(E)} \mathrm{High} \mathrm{magnification} \mathrm{of} \mathrm{(C)} \mathrm{showing} \alpha 7$ nAChRs immunoreactivity processes of pigment epithelium cells located between photoreceptor outer segments, marked by arrows. (F) High magnification of (D). Nuclei stained with TOPRO-3 in blue. Bar $20 \mu \mathrm{m}$. CHO, Choroid; OS, Photoreceptor outer segments.

cells, including epithelial, endothelial, or immune cells, and it can play different roles in cell biology and homeostasis with biological and clinical significance (Grando, 2008; Kawashima \& Fujii, 2008; Wessler \& Kirkpatrick, 2008). In the eye, the role of nonneuronal cholinergic system has not yet been widely studied. However, if we take into account the relevant roles of this system in most other tissues, it would not be surprising to find similar roles in retina and

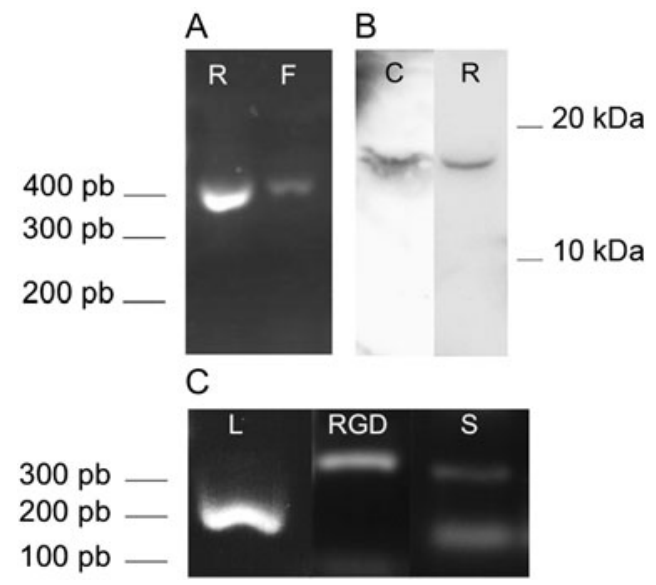

Fig. 5. Retinal expression of nAChRs' endogenous modulators. (A) RT-PCR amplification with lynx 1 specific oligonucleotides from bovine retina $(\mathrm{R})$ and freshly isolated RPE (F). (B) Western blot showing immunoreactive bands obtained with lynx1 antibody in total bovine retinal extract proteins (R). Band obtained from rat brain is shown as positive control (C). (C) RT-PCR amplification from rat retinal total RNA using specific lynx1 (L), RGD1308195 (RGD), and SLURP-1 (S) oligonucleotides.
RPE layers. In this sense, one could expect the presence of nonneuronal nAChRs in RPE given that they are expressed in numerous epithelial cells from different tissues, such as airway surface epithelium, alveolar type 2 cells, skin (e.g., keratinocytes and melanocytes), intestine (e.g., surface epithelium or colonic epithelial cell line), ovary, or urothelium (Wessler \& Kirkpatrick, 2008).

In this work, nicotinic subunit $\alpha 7$ transcripts were detected in bovine RPE by RT-PCR, and protein expression was confirmed by Western blot and immunocytochemistry. Protein expression was detected in both freshly isolated and cultured bovine RPE after four passages. Immunofluorescence was mostly distributed around the cell nucleus and may be associated with the endoplasmic reticulum, as described for $\alpha 7 \mathrm{nAChRs}$ in rat hippocampus by Fabian-Fine et al. (2001) and on glutamatergic axon terminals in the rat ventral tegmental area by Jones and Wonnacott (2004).

Immunohistochemistry in sections of rat retina showed fluorescence in RPE layer, indicating that $\mathrm{nAChRs}$ are expressed in the RPE layer under normal conditions. As supporting data of RPE expression of nAChRs, we also detected the expression of $\alpha 3$ nicotinic receptors in RPE, at least at the mRNA level (not shown).

Our data indicate that cultured RPE cells, at least at early culture passages, seem to be a good model for studying nicotinic receptor composition and function in RPE. They are also useful in studying the relationship of nAChRs and the retina and the role in the visual system. In order to characterize our cell cultures and to discard other cell type contamination, expression of the RPE-specific markers CRALBP and RPE65 was tested and confirmed by RTPCR. Moreover, CRALBP expression was detected by immunocytochemistry, with $100 \%$ of the cells being positively stained. To our knowledge, nicotinic receptors have been described in the eye in bipolar, amacrine, and ganglion cells (Dmitrieva et al., 2007). 
However, any probability of neuronal survival was eliminated after four culture passages (about 2 months of culture). Under better conditions, retinal ganglion cells can survive for about 4 weeks without successive passages (Romano \& Hicks, 2007). Furthermore, while the medium used is suitable for RPE cells, it lacks enrichment factors to promote neuronal survival. Cell contamination could also come from nonneuronal cells, such as fibroblasts, but this possibility has also been discarded, since the presence of these cells would be evident in the first two culture passages, since RPE cells grow slowly and their melanin granules give them a characteristic morphology ( $\mathrm{Lu}$ et al., 2007).

Since evidence exists showing that $\mathrm{nAChRs}$ are modulated by hypoxia, we have carried out studies to determine if RPE nAChRs are also modulated by oxidative stress. Expression of $\alpha 7 \mathrm{nAChRs}$ appeared to be modulated by long-term hypoxia, decreasing its expression after $72 \mathrm{~h}$ of hypoxic stimulus. These data are in accordance with data of Ducsay et al. (2007). The biological or clinical relevance of this result should be clarified.

Calcium imaging analysis was used to test for the presence of functional nAChRs in cultured RPE cells. It is well known that adequate stimulation of nAChRs induces $\mathrm{Ca}^{2+}$ influx through ion pores (Fucile et al., 2004), which can be detected by monitoring intracellular calcium levels (Lax, 2008). The calcium transients measured will vary depending on both current amplitude and fractional $\mathrm{Ca}^{2+}$ permeability. In cultured cerebellar granule neurons (CGN), cells with detectable $\mathrm{Ca}^{2+}$ transients displayed nicotineevoked currents more than three times larger than those from randomly recorded cells (Fucile et al., 2004). In our experiments, the percentage of cells with detectable $\mathrm{Ca}^{2+}$ transients were $0.18 \%$ for $200 \mu \mathrm{M}$ nicotine and $0.21 \%$ for $200 \mu \mathrm{M}$ acethylcholine plus $0.5 \mu \mathrm{M}$ atropine. The low number of cells with measurable responses contrast with the immunostaining in Fig. 1F. This difference could be due to (a) the low sensibility of the calcium imaging analysis, in part because of the thinness of RPE cells; (b) cytoplasmic location of nAChRs and/or; (c) low functionality of nAChRs in RPE cultured cells, for example, because of endogenous modulation.

These results per se can neither confirm nor reject the role of nAChRs as traditional neurotransmitter-gated ion channels in RPE. On one hand, they are very similar to those reported in previous experiments in which $\mathrm{Ca}^{2+}$ transients were measured in CGN (Fucile et al., 2004; Lax, 2008); however, on the other hand, the small number of cells responding to nicotinic agonist stimulus could better fit with a role in the nonneuronal cholinergic system in the RPE.

Since there is increasing evidence of the relevant role of nonneuronal $\mathrm{nAChRs} \mathrm{ligands} \mathrm{in} \mathrm{nicotinic} \mathrm{function} \mathrm{and} \mathrm{modulation}$ (Miwa et al., 1999; Grando, 2008; Kawashima \& Fujii, 2008), we tested and confirmed the expression of lynx1, the endogenous modulator of $\alpha 7$ receptor, in the bovine retina and RPE. We also showed the expression of other members of the Ly-6/neurotoxin gene family in rat retina: lynx1, RGD1308195, and SLURP-1. These data support the idea that nicotinic receptors in RPE may have a significant role in aspects similar to those observed in other epithelial cells (Grando, 2008; Kawashima \& Fujii, 2008).

We propose that nAChRs in RPE could be involved in cell protection mechanisms. Available data show that nicotine and some nicotinic agonists exert a protective role against amyloid betainduced toxicity through nAChRs (Kihara et al., 1999; Shimohama \& Kihara, 2001; Martin et al., 2004; de Fiebre \& de Fiebre, 2005). In this regard, it is known that amyloid beta depositions (a major component of senile plaques found in Alzheimer's patients) are present in RPE drusen of patients with age-related macular degeneration (AMD), and accumulation of this peptide induces RPE atrophy (Yoshida et al., 2005). AMD is one of the leading causes of irreversible vision loss and blindness in industrialized countries, occurring in about $10-25 \%$ of people over 65 years of age (Klein et al., 1992; Zarbin, 1998; Klaver et al., 2001; Chakravarthy et al., 2010). On the other hand, in PC12 cells, it has been demonstrated that during early stages of damage by oxidative stress, there is a reduction in $\alpha$-bungarotoxin binding sites and expression of nAChRs selectively decreases (Guan et al., 2001).

In the mechanisms of cell protection involving nAChRs, endogenous modulators such as SLURP1, SLURP2, or lynx1 can play a relevant role. In this sense, it has been reported that endogenous ligand SLURP1 binds to $\alpha 7 \mathrm{nAChRs}$ and facilitates apoptosis, while SLURP2 binds to $\alpha 3 \mathrm{nAChRs}$ and prevents apoptosis (Arredondo et al., 2005, 2006, 2007; Moriwaki et al., 2007).

Future studies should be conducted in order to clarify the subunit composition of nAChRs in RPE cells and to understand $n A C h R s$ function under normal and pathological conditions. We can conclude that RPE cells express $\alpha 7 \mathrm{nAChRs}$ as well as at least one endogenous nicotinic modulator, lynx 1 . These receptors may be involved in the pathological progression of ocular degenerative diseases, such as AMD, and their study could provide new therapeutic approaches for achieving successful treatments.

\section{Acknowledgments}

We are grateful to both Dr. Jonathan Rojo for his assistance in optimizing Western blot conditions and his additional help and to Laura Campello for kindly providing rat retinal mRNA. We also would like to thank Miguel Ángel Company for his technical assistance. This work was supported by Spanish Ministerio de Educación y Ciencia (grants BFU 2007-60658/BFI and BFU2009-07793/BFI) and Ministerio de Sanidad y Consumo (grant RETICS RD07/0062/0012).

\section{References}

Arredondo, J., Chernyavsky, A.I. \& Grando, S.A. (2007). Overexpression of SLURP-1 and -2 alleviates the tumorigenic action of tobaccoderived nitrosamine on immortalized oral epithelial cells. Biochemical Pharmacology 74, 1315-1319.

Arredondo, J., Chernyavsky, A.I., Jolkovsky, D.L., Webber, R.J. \& GRANDO, S.A. (2006). SLURP-2: A novel cholinergic signaling peptide in human mucocutaneous epithelium. Journal of Cellular Physiology 208, 238-245.

Arredondo, J., Chernyavsky, A.I., Webber, R.J. \& Grando, S.A. (2005). Biological effects of SLURP-1 on human keratinocytes. The Journal of Investigative Dermatology 125, 1236-1241.

Benhammou, K., Lee, M., Strook, M., Sullivan, B., Logel, J., Raschen, K., GotTi, C. \& LeOnard, S. (2000). [(3)H]Nicotine binding in peripheral blood cells of smokers is correlated with the number of cigarettes smoked per day. Neuropharmacology 39, 2818-2829.

Blank, U., Ruckes, C., Clauss, W. \& Weber, W.M. (1997). Effects of nicotine on human nasal epithelium: Evidence for nicotinic receptors in non-excitable cells. Pflugers Arch 434, 581-586.

Chakravarthy, U., Evans, J. \& Rosenfeld, P.J. (2010). Age related macular degeneration. BMJ 340, 526-530.

Chernyavsky, A.I., Arredondo, J., Marubio, L.M. \& Grando, S.A. (2004). Differential regulation of keratinocyte chemokinesis and chemotaxis through distinct nicotinic receptor subtypes. Journal of Cell Science 117, 5665-5679.

Criado, M., Dominguez, T.E., Carrasco-Serrano, C., Smillie, F.I., Juiz, J.M., Viniegra, S. \& Ballesta, J.J. (1997). Differential expression of alpha-bungarotoxin-sensitive neuronal nicotinic receptors in adrenergic chromaffin cells: A role for transcription factor Egr-1. The Journal of Neuroscience 17, 6554-6564.

DE Fiebre, N.C. \& DE Fiebre, C.M. (2005). alpha7 Nicotinic acetylcholine receptor knockout selectively enhances ethanol-, but not beta-amyloidinduced neurotoxicity. Neuroscience Letters 373, 42-47. 
Dmitrieva, N.A., Strang, C.E. \& Keyser, K.T. (2007). Expression of alpha 7 nicotinic acetylcholine receptors by bipolar, amacrine, and ganglion cells of the rabbit retina. The Journal of Histochemistry and Cytochemistry 55, 461-476.

Ducsay, C.A., Hyatt, K., MlynarczyK, M., Root, B.K., Kaushal, K.M. \& MYERS, D.A. (2007). Long-term hypoxia modulates expression of key genes regulating adrenomedullary function in the late gestation ovine fetus. American Journal of Physiology. Regulatory, Integrative and Comparative Physiology 293, R1997-R2005.

Fabian-Fine, R., Skehel, P., Errington, M.L., Davies, H.A., Sher, E. Stewart, M.G. \& Fine, A. (2001). Ultrastructural distribution of the alpha7 nicotinic acetylcholine receptor subunit in rat hippocampus. The Journal of Neuroscience 21, 7993-8003.

Favre, B., Plantard, L., Aeschbach, L., Brakch, N., Christen-Zaech, S., De Viragh, P.A., Sergeant, A., Huber, M. \& Hohl, D. (2007) SLURP1 is a late marker of epidermal differentiation and is absent in $\mathrm{Ma}$ de Meleda. The Journal of Investigative Dermatology 127, 301-308.

Fucile, S., Renzi, M., Lauro, C., Limatola, C., Ciotti, T. \& Eusebi, F. (2004). Nicotinic cholinergic stimulation promotes survival and reduces motility of cultured rat cerebellar granule cells. Neuroscience 127, 53-61.

Gotti, C. \& Clementi, F. (2004). Neuronal nicotinic receptors: From structure to pathology. Progress in Neurobiology 74, 363-396.

Grando, S.A. (2008). Basic and clinical aspects of non-neuronal acetylcholine: Biological and clinical significance of non-canonical ligands of epithelial nicotinic acetylcholine receptors. Journal of Pharmacological Science 106, 174-179.

Guan, Z.Z., Zhang, X., Mousavi, M., Tian, J.Y., Unger, C. \& Nordberg, A. (2001). Reduced expression of neuronal nicotinic acetylcholine receptors during the early stages of damage by oxidative stress in PC12 cells. Journal of Neuroscience Research 66, 551-558.

Heeschen, C., Weis, M., Aicher, A., Dimmeler, S. \& Cooke, J.P. (2002). A novel angiogenic pathway mediated by non-neuronal nicotinic acetylcholine receptors. The Journal of Clinical Investigation $\mathbf{1 1 0}$ 527-536.

Jones, I.W. \& WonnacotT, S. (2004). Precise localization of alpha7 nicotinic acetylcholine receptors on glutamatergic axon terminals in the rat ventral tegmental area. The Journal of Neuroscience 24, 11244 11252.

Kawashima, K. \& FujII, T. (2008). Basic and clinical aspects of nonneuronal acetylcholine: Overview of non-neuronal cholinergic systems and their biological significance. Journal of Pharmacological Science 106, 167-173.

Kihara, T., Shimohama, S. \& Akaike, A. (1999). Effects of nicotinic receptor agonists on beta-amyloid beta-sheet formation. The Japanese Journal of Pharmacology 79, 393-396.

Klaver, C.C., Assink, J.J., VAn LeEuWen, R., Wolfs, R.C., Vingerling, J.R., Stijnen, T., Hofman, A. \& DE Jong, P.T. (2001). Incidence and progression rates of age-related maculopathy: The Rotterdam Study. Investigative Ophthalmololgy \& Visual Science 42, 2237-2241.

Klein, R., Klein, B.E. \& Linton, K.L. (1992). Prevalence of agerelated maculopathy. The Beaver Dam Eye Study. Ophthalmology 99 933-943.

LAX, P. (2008). Melatonin inhibits nicotinic currents in cultured rat cerebellar granule neurons. Journal of Pineal Research 44, 70-77.

Lindstrom, J. (1997). Nicotinic acetylcholine receptors in health and disease. Molecular Neurobiology 15, 193-222.

Lu, F., Yan, D., Zhou, X., Hu, D.N. \& Qu, J. (2007). Expression of melanin-related genes in cultured adult human retinal pigment epithelium and uveal melanoma cells. Molecular Vision 13, 2066-2072.

Macklin, K.D., Maus, A.D., Pereira, E.F., Albuquerque, E.X. \& ConTi-Fine, B.M. (1998). Human vascular endothelial cells express functional nicotinic acetylcholine receptors. The Journal of Pharmacology and Experimental Therapeutics 287, 435-439.

Marritt, A.M., Cox, B.C., Yasuda, R.P., McIntosh, J.M., XiaO, Y., Wolfe, B.B. \& Kellar, K.J. (2005). Nicotinic cholinergic receptors in the rat retina: Simple and mixed heteromeric subtypes. Molecular Pharmacology 68, 1656-1668.

Martin, S.E., De Fiebre, N.E. \& De Fiebre, C.M. (2004). The alpha7 nicotinic acetylcholine receptor-selective antagonist, methyllycaconitine, partially protects against beta-amyloid (1-42) toxicity in primary neuron-enriched cultures. Brain Research 1022, 254-256.

Mastrangeli, R., Donini, S., Kelton, C.A., He, C., Bressan, A., Milazzo, F., Ciolli, V., Borrelli, F., Martelli, F., Biffoni, M., Serlupi-Crescenzi, O., Serani, S., Micangeli, E., El Tayar, N.,
VACCARO, R., Renda, T., Lisciani, R., Rossi, M. \& PAPOIAN, R. (2003) ARS component B: Structural characterization, tissue expression and regulation of the gene and protein (SLURP-1) associated with Mal de Meleda. European Journal of Dermatology 13, 560-570.

Maus, A.D., Pereira, E.F., Karachunski, P.I., Horton, R.M., Navaneetham, D., Macklin, K., Cortes, W.S., Albuquerque, E.X. \& Conti-Fine, B.M. (1998). Human and rodent bronchial epithelial cells express functional nicotinic acetylcholine receptors. Molecular Pharmacology 54, 779-788.

Millar, N.S. (2003). Assembly and subunit diversity of nicotinic acetylcholine receptors. Biochemical Society Transactions 31, 869-874.

Miwa, J.M., Ibanez-Tallon, I., Crabtree, G.W., Sánchez, R., Sali, A., Role, L.W. \& Heintz, N. (1999). lynx1, an endogenous toxin-like modulator of nicotinic acetylcholine receptors in the mammalian CNS. Neuron 23, 105-114.

Miwa, J.M., Stevens, T.R., King, S.L., Caldarone, B.J., IbanezTallon, I., Xiao, C., Fitzsimonds, R.M., Pavlides, C., Lester, H. A., Picciotto, M.R. \& Heintz, N. (2006). The prototoxin lynx 1 acts on nicotinic acetylcholine receptors to balance neuronal activity and survival in vivo. Neuron 51, 587-600.

Moretti, M., Vailati, S., Zoli, M., LiPPi, G., Riganti, L., Longhi, R., Viegi, A., Clementi, F. \& Gotti, C. (2004). Nicotinic acetylcholine receptor subtypes expression during rat retina development and their regulation by visual experience. Molecular Pharmacology 66, 85-96.

Moriwaki, Y., Yoshikawa, K., Fukuda, H., Fuji, Y.X., Misawa, H. \& KAWASHIMA, K. (2007). Immune system expression of SLURP-1 and SLURP-2, two endogenous nicotinic acetylcholine receptor ligands. Life Sciences 80, 2365-2368.

Newhouse, P.A., Potter, A. \& Levin, E.D. (1997). Nicotinic system involvement in Alzheimer's and Parkinson's diseases. Implications for therapeutics. Drugs Aging 11, 206-228.

Nguyen, V.T., Ndoye, A., Hall, L.L., Zia, S., Arredondo, J., Chernyavsky, A.I., Kist, D.A., Zelickson, B.D., Lawry, M.A. Grando, S.A. (2001). Programmed cell death of keratinocytes culminates in apoptotic secretion of a humectant upon secretagogue action of acetylcholine. Journal of Cell Science 114, 1189-1204.

Raviola, E. \& Wiesel, T.N. (1985). An animal model of myopia. The New England Journal of Medicine 312, 1609-1615.

Romano, C. \& Hicks, D. (2007). Adult retinal neuronal cell culture. Progress in Retinal Eye Research 26, 379-397.

Sato, K.Z., Fuji, T., Watanabe, Y., Yamada, S., Ando, T., Kazuko, F. \& Kawashima, K. (1999). Diversity of mRNA expression for muscarinic acetylcholine receptor subtypes and neuronal nicotinic acetylcholine receptor subunits in human mononuclear leukocytes and leukemic cell lines. Neuroscience Letters 266, 17-20.

Shimohama, S. \& Kinara, T. (2001). Nicotinic receptor-mediated protection against beta-amyloid neurotoxicity. Biological Psychiatry 49, 233-239.

Stone, R.A., Lin, T. \& Laties, A.M. (1991). Muscarinic antagonist effects on experimental chick myopia. Experimental Eye Research 52, $755-758$.

Stone, R.A., Sugimoto, R., Gill, A.S., Liu, J., Capehart, C. \& LindsTrom, J.M. (2001). Effects of nicotinic antagonists on ocular growth and experimental myopia. Investigative Ophthalmololgy \& Visual Science 42, 557-565.

Tigges, M., Iuvone, P.M., Fernandes, A., Sugrue, M.F., Mallorga, P J., LAties, A.M. \& Stone, R.A. (1999). Effects of muscarinic cholinergic receptor antagonists on postnatal eye growth of rhesus monkeys. Optometry and Vision Science 76, 397-407.

Toyabe, S., Iiai, T., Fukuda, M., Kawamura, T., Suzuki, S., Uchiyama, M. \& Аво, T. (1997). Identification of nicotinic acetylcholine receptors on lymphocytes in the periphery as well as thymus in mice. Immunology 92, 201-205.

Utsugisawa, K., Nagane, Y., Obara, D. \& Tohgi, H. (2002). Overexpression of alpha7 nicotinic acetylcholine receptor prevents G1-arrest and DNA fragmentation in PC12 cells after hypoxia. Journal of Neurochemistry 81, 497-505.

Vailati, S., Moretti, M., Longhi, R., Rovati, G.E., Clementi, F. \& Gotт, C. (2003). Developmental expression of heteromeric nicotinic receptor subtypes in chick retina. Molecular Pharmacology 63, 13291337.

Vogel, J.S., Bullen, E.C., Teygong, C.L. \& Howard, E.W. (2007) Identification of the RLBP1 gene promoter. Investigative Ophthalmololgy \& Visual Science 48, 3872-3877. 
Wang, Y., Pereira, E.F., Maus, A.D., Ostlie, N.S., Navaneetham, D., Lei, S., Albuquerque, E.X. \& Conti-Fine, B.M. (2001). Human bronchial epithelial and endothelial cells express alpha7 nicotinic acetylcholine receptors. Molecular Pharmacology 60, 1201-1209.

Wessler, I. \& KirkPATRICK, C.J. (2008). Acetylcholine beyond neurons: The non-neuronal cholinergic system in humans. British Journal of Pharmacology 154, 1558-1571.

Yoshida, T., OHno-Matsui, K., Ichinose, S., Sato, T., Iwata, N., Saido, T.C., Hisatomi, T., Mochizuki, M. \& Morita, I. (2005). The potential role of amyloid beta in the pathogenesis of age-related macular degeneration. The Journal of Clinical Investigation 115, 2793-2800.
Yuan, Y.Q., Van Soom, A., Coopman, F.O., Mintiens, K., Boerjan, M. L., Van Zeveren, A., De Kruif, A. \& Peelman, L.J. (2003). Influence of oxygen tension on apoptosis and hatching in bovine embryos cultured in vitro. Theriogenology 59, 1585-1596.

ZARBIN, M.A. (1998). Age-related macular degeneration: Review of pathogenesis. European Journal of Ophthalmology 8, 199-206.

Zia, S., Ndoye, A., Lee, T.X., Webber, R.J., Grando, S.A. (2000). Receptor-mediated inhibition of keratinocyte migration by nicotine involves modulations of calcium influx and intracellular concentration. Journal of Pharmacology and Experimental Therapeutics 293, 973-981. 